IRA-International Journal of Education \& Multidisciplinary Studies

ISSN 2455-2526; Vol.04, Issue 01 (2016)

Institute of Research Advances

http://research-advances.org/index.php/IJEMS

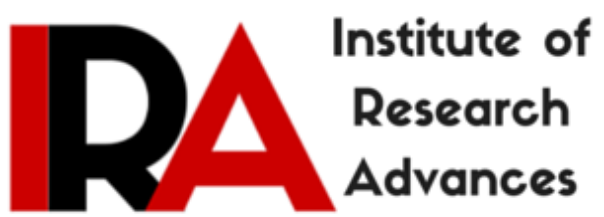

\title{
Oriental Approach to Environmental Protection and Perspective of Media
}

\author{
Dr. Sunil Kumar Mishra, \\ Asst. Professor, \\ Vivekananda Institute of Professional Studies, \\ New Delhi, India.
}

DOI: http://dx.doi.org/10.21013/jems.v4.n1.p12

\section{How to cite this paper:}

Mishra, S. (2016). Oriental Approach to Environmental Protection and Perspective of Media. IRA International Journal of Education and Multidisciplinary Studies (ISSN 2455-2526), 4(1). doi:http://dx.doi.org/10.21013/jems.v4.n1.p12

(C) Institute of Research Advances

\section{(cc) EY-NC}

This works is licensed under a Creative Commons Attribution-Non Commercial 4.0 International License subject to proper citation to the publication source of the work.

Disclaimer: The scholarly papers as reviewed and published by the Institute of Research Advances (IRA) are the views and opinions of their respective authors and are not the views or opinions of the IRA. The IRA disclaims of any harm or loss caused due to the published content to any party. 
Introduction- Environment is all persistent. It is the region of our existence. It envelops us. Since, we know that Nature, mother of human beings, has blessed us with a beautiful environment and as per environmental determinism, environment decides human lifestyle. There is a reciprocal relationship between the mankind and the environment. Environment fulfills our all needs but due to our greed, we harm it in many ways. In the name of so called development human has indulged himself in various activities like deforestation, air pollution, soil pollution, water pollution, global warming etc. which is leading towards environmental weakening. If we want to save ourselves, we must be sensitive towards environment. We can find various ways to respect our environment in Sanskrit literature. The Rigveda venerates deities like Mitra, Varuna, Indra, Maruts and Aditya, that are responsible for maintaining the requisite balance in the functioning of all entities of nature whether the mountains, lakes, heaven and earth, the forests or the waters. Yajurveda, which is one of the most valuable literature of sanskrit has been seen as great advocate of environmental protection. The meaning of Yajurveda describes a dynamic thing which travels in sky. Yajurveda advocates a great respect towards every component of environment.' Om dayoh shanti rantriksham shantih, prithvi shanti raapah shantiroshdhayah shantih. Vanaspatayah shantirvishwe devah shanti brahm shantih, sarvam shantih shantirev shantih sa ma shantiredhi. Om shantih shantih shantih. ${ }^{1}$ means "May peace radiate there in the whole sky as well as in the vast ethereal space everywhere. May peace reign all over this earth, in water and in all herbs, trees and creepers. May peace flow over the whole universe. May peace bein the supreme being brahman. And may there always exist in all peace and peace alone. Aum peace, peace, and peace to us and all begins. The sages of the Atharva Veda chanted 'what of thee I dig out, let that quickly grow over, let me not hit thy vital, or thy heart.' This means that one can take from the earth and atmosphere only so much as one puts back to them. In present days, this is considered one of the most important principles of sustainable development. The purity and quality of water has been highlighted in the Atharva Veda. It is mentioned that pure water cures many ailments and it acts as preventer of the diseases which are not yet contracted. Atharva Veda also speaks about the protection of wildlife and domestic cattle. The cattle were meant to adorn the ceremony but not for sacrifice." ${ }^{2}$ When we take bath we worship river and respect this source of water as "Gange cha Yamune chaiva,Saraswathi, Godhaavari, "Taambraparni "Narmathe,Zindhu,Kaveri Jalesmin Zannithim Kuru." In our Vedas every component of environment has been described as valuable and precious things for our existence. It also draws our attention on the philosophy of sustainable development.

Media have power to convey the message of these religious books and help to protect environment. Media can sensitize people to respect environment and go through the process of sustainable development to save natural resources for next generation. Media play vital role in creating awareness among people on various environmental issues. From its primary goal of to inform, educate and aware; it encourage, appreciate and motivate people to save environment. Since, we know that Nature, mother of human beings, has blessed us with a beautiful environment. It is a sum total of precious things like land, water, air and all living and non-living things.

Media can sensitize people to respect environment and go through the process of sustainable development to save natural resources for next generation. The availability of non- renewable resources is limited while we don't have a foolproof plan to use renewable resources in proper manner. To fulfill daily needs we exploit natural resources but show casual approach in terms of its substitution. Lyla Bavadam points out, "there are issues that most people do not think are important as they do not impact people's lives and so nobody sees environmental issues as their responsibility" ${ }^{\prime 3}$. Media has power to create the sense of responsibility towards environment among people. If we want to save ourselves, we must be sensitive towards environment. With quality of preservation for future references, print media has potential to aware people. From its beginning, print media has been seen as great advocate of environment. National dailies can raise environmental issues at heterogeneous level and help people to understand and save environment. However the necessity of being literate is main drawback which creates hurdles in its way. 
Methodology- This paper analysis the rhymes of 'Vedas' on environmental issues and calculates the coverage of environmental issues in National dailies: The Times of India \& the Hindustan Times (English) and Navbharat Times \& Hindustan (Hindi) published from Delhi- NCR. For this purpose content analysis method has been adopted to analyze newspapers published in the month of February, 2016 for seven days. The main objective of this study is to find total coverage of environmental issues in above mentioned national dailies. Apart from this, the present study analyzes the ancient and present approach of environmental protection.

\section{Climate Change: A Threat to Civilization-}

In the midst of modernization and development that humankind achieved, a gradual change in the ecosystem is also witnessing day by day. With the world facing maximum rise in temperature, water crisis, storm and heat wave, the issue of climate change has become a major concern all over the world. In India, during the past 10 years, we have seen major changes in climate and environmental degradation. Last year more than 1,300 people died in Andhra Pradesh and Telangana due to heat wave. Several people died in Jammu and Kashmir due to heavy rain and flood last year while Jammu and Kashmir never saw such climate in past century. These incidents warn us not to play with nature. Prof. P.D. Sharma says, "As a result of increasing human population and impact of its activities on natural resources, earth's environment has been undergoing significant changes, especially during 20th century. One of the most significant changes brought about by human activities is an increase in the concentration of carbon dioxide and other greenhouse gases in the atmosphere (troposphere)" 4 .

According to the United Nation's report, due to the hazardous consequences of climate change, Mumbai and Kolkata can lost its existence by 2070 . One of the most significant changes brought about by human activities is an increase in the concentration of carbon dioxide and other greenhouse gases, which is totally unfit for human existence. Due to industrialization, we have increased pollution level which is the main cause of climate change. According to Prof. H. M. Saxena, "since the beginning of the Industrial Revolution humans have been taking stored carbon out of the earth in the form of coal, petroleum and natural gas, and burning it to make carbon dioxide, heat, water vapor and small amounts of sulphar dioxide (SO2) and other gases, which are responsible for air pollution, greenhouse effect, increase in surface temperature, or in other words, global warming. By 2050, it is possible that the increase in global surface temperatures between 1.4 and 2.2 degree Celsius", Due to humankind's unending industrialization process, the pollution level increases tremendously. The ultimate result is the climate change in the form of global warming, unseasoned heavy rain, increasing surface temperature of earth, flood, land sliding, radiation, damage of ozone layer, etc. Earth, water and air - the basic necessities of life, have become heavily polluted.

In view of the increasing pollution in Yamuna river, recently the Delhi High Court has ordered the civic agencies of Delhi to come with a strong master program for cleaning the Yamuna, which has been converted into a drain river. People from the Delhi and NCR are facing many health problems due to the polluted river water. Air pollution, also seems to have a direct and negative impact on the grain production in India. According to a US study, the recent increase in smog decreases projected yields by half. Delhi and nearby areas are witnessing pollution levels touching $800 \mathrm{ug} / \mathrm{m} 3$ whereas annual average in 2011 was $262 \mathrm{ug} / \mathrm{m} 3$. According to a report by the Central Pollution Control Board, level of air pollution is also increasing in small cities while five years ago, only industrial and big cities like Delhi, Ludhiana, Indore, Kanpur were hubs for country's dirty air. The role of mass media in communicating climate change has been characterized by a long period of passivity and alarmism. Media coverage of climate change across the globe has increased since the late 1980's and has gained momentum from the early 2000. Media shows real picture of climate change and its impact on species time to time and helps to make changes in policies and its implementation. 


\section{Ancient Approach of Environmental Protection-}

Natural phenomenon, elements, species and processes have described as a God/Goddess in our ancient literature. In Hinduism, we find that from Vedic period, the environment was part of ethos of ancient people. Prof. P.S. Jaiswal writes, "In Rig Veda, it is mentioned that the universe consist of five basic elements. They are Earth, Water, Air, Fire and Space. These five elements provide the basis for life in everything and man is ordained to conserve them. It is further ordained that nobody will destroy vegetation and no one shall kill animals. Thus, it shows compassion for both animals and plants". ${ }^{6}$ In our Vedas, different animals and birds are associated with different Gods or Goddesses and thus they are either worshiped or emphasis is on their protection and preservation. Birds and Animals associated with God and Goddesses are given below:

\begin{tabular}{|l|l|}
\hline God/ Goddess & Animal/ Bird \\
\hline Ganesh & Rat \\
\hline Laxmi & Owl \\
\hline Shiva & Bull \\
\hline Vishnu & Eagle \\
\hline Indra & Elephant \\
\hline Sun & Horse \\
\hline Durga & Lion \\
\hline
\end{tabular}

Trees and plants also occupy a very special place in Hinduism, so much so that they are not only worshiped but considered as the abode of various God and Goddesses. Tulsi, Bela, Pipal, Ashoka, Kadamb and Durva are used to worship different God and Goddesses. The killing of animals in the name of Yajna has been condemned as mad and in disciplined acts in Mahabharta. The Padma Puran mentions that those who sacrifice cattle are doomed to predation. In Manusmriti, the cruelty towards animals has been condemned. It is stated that the killer of the cattle is doomed to die as many times as there are hair on the skin of cattle. Killing of animals is prohibited in Vedas also. As wrote in Puran, 'Pakshi dagdham sudurbuddhe papatman sampratam vritha, vrithasnanam vritha tirtham vritha japt vritha hatam' which means all acts of worship and pilgrimage are worthless if a man kills birds and animals. S.L. Kale and Vipin Choudhary wrote, "Most of the religions appeared at an age when environmental crisis was almost nonexistent, still their teachings strongly emphasize man's intimate relationship with nature. All primitive religions involved worship of nature, sun, moon, stars, water, trees, plants, animals, birds, closely linking man with nature. The impact of these natural cults can essentially be seen on religions like Hinduism where worship of flora and fauna is very common."7 There are various rituals and customs which strongly advocate the protection of environment. The ancient Indian law on environment protection is found in Kautilya's 'Arthshashtra'. It was the dharma of each individual in the society to protect the nature. The people worshiped the objects of nature. The trees, water, land and animal gained important position in ancient time.

Media Perspective on Environmental Protection- Media is very important tool of image creation and influencing public perception because of their reach across almost population and its ability to convey message among heterogeneous public. It has power to change public perception over an issue and involve them in process of change. Media is powerful agent of social change. In a democratic country like India, It works like a teacher to sensitize public over different Environmental issues. From its primary goal of to inform, educate and aware; it creates a sense to respect environment. It also help people to understand the importance of natural resources and follow the concept of sustainable development where people not focus on present generation only but also think about up-coming generation. Kaushik and Kaushik define sustainable development as "meeting the needs of the present without compromising the ability of future 
generations to meet their own needs" ${ }^{\text {. }}$. Process of sustainable development can help to meet out several environmental problems.

Media encourage people to participate in the process of save environment-save life. 'Chipko and Apiko Movement' achieved the goal because of media. Media created a platform for many movements where thousands of environment activists get together and raised their voice to protect environment. It also motivates government to make strong policies for environmental protection. During the formation and amendment of 'The Wildlife Protection Act-1972, Water (Prevention and Control of Pollution) Act-1974, Forest Conservation Act- 1980, Air (Prevention and Control of Pollution) Act-1981, and Environmental Protection Act- 1986; media motivated the government to bring out a law according to present requirement. It also motivated public to participate in the process of sustainable development and to help in implementation of government policies. Media motivates people to participate in various schemes like 'Clean Ganga and Yamuna', 'Save Tiger', 'Clean India Campaign', 'Plant tree', and 'construct Toilet' run by government.

Media also appreciates the efforts of all those people who are working for environmental protection. People like 'Peepal baba' of Delhi was appreciated by media for planting millions peepal tree while a woman of Maharashtra who sold her mangal- sutra for the construction of toilet, was also appreciated by media. Media appreciated two girls of Haryana who took ninth fera to save environment in their marriage. Media not only appreciate government policies but also criticize all that decision which can harm environment in any way. Recently Media criticize the steps of NDA government to make changes in environmental laws to speed up development projects. R. Rajagopalan writes, "There are many factors that limit our awareness of environmental issues. To the millions of poor people, the problems of daily existence are more important than environmental degradation. The more prosperous are afraid that, in the name of environment, their comforts may be taken away" "Here media is only tool which can show the real picture of environmental degradation and its impact on human being where men look like puppet of nature. During Uttarakhand and J \& K calamity media helped to understand several environmental issues and presented the picture of men and environment conflict where men seem helpless.

From its birth, print media has been seen as great advocate of social issues. Bal Ganga dhar Tilak, Kusha Bhau Thakre, Vishnu Rao Paradkar, Mahatma Gandhi, Ganesh Shankar Vidyarthi, Rajendra Yadav, Prabhash Joshi and several people raised voice for social cause and tried to aware people on various environmental issues. Newspapers have strong place in the era of new media. Increasing literacy rate, better transportation facility and multi-edition publication helped news paper's organization to increase its readers. A great anxiety towards pollution, climate change, calamity, global warming etc. can be seen in national dailies where hard stories covers all types of environmental problem and point out the reason behind it. These stories also suggest the way to save environment and help people to understand the importance of natural resources and its proper utilization.

Content on environmental issues of Hindi daily 'Navbharat Times' \& 'Hindustan' and English dailies 'The Times of India' \& 'Hindustan Times' have been analyzed to see total coverage area, placement, treatment etc.

A. The Times of India- TOI is most circulated English paper of India but also no.1 paper of DelhiNCR.

Table-1

\begin{tabular}{|l|l|l|l|l|}
\hline Date & Size of Story & $\begin{array}{l}\text { Placement \& } \\
\text { Treatment }\end{array}$ & Environmental Issue & Total Area \\
\hline $20-02-2016$ & 96 & P-7 & Pollution & $96 / 66096$ \\
\hline $21-02-2016$ & No space & ------ & -------- & $00 / 55080$ \\
\hline
\end{tabular}




\begin{tabular}{|l|l|l|l|l|}
\hline $22-02-2016$ & 1250, & P-11, & Cyclone, Black-hole & $1394 / 44064$ \\
& 144 & P-17 & & \\
\hline $23-02-2016$ & 384, & P-9 & Earthquake & $752 / 47736$ \\
& 200, & P-13 & Water law & \\
& 168 & P-22 & Nuclear energy & \\
\hline $24-02-2016$ & 448, & P-6, & Water Crisis, & $832 / 62424$ \\
& 160, & P-18, & Wild life, & \\
& 224 & P-27 & Sea level rising & \\
\hline $25-02-2016$ & 220, & P-6 & Water crisis & $540 / 47736$ \\
& 320 & P-7 & Pollution & \\
\hline $26-02-2016$ & 120 & P-23 & Bio-diversity & $120 / 55080$ \\
\hline
\end{tabular}

On the basis of table no.1 we can very less space have been used for such issues however almost all issues got attention. Pollution and Climate Change are most published issue in TOI. Different types of pollution and its impact on society have been pointed out time to time.

B. The Hindustan Times- Hindustan Times is the most popular paper of Delhi- NCR. It is basically youth oriented paper which is liked by college going students most. Its circulation is increasing day by day and after TOI it is on second position on the basis of readership.

Table-2

\begin{tabular}{|l|l|l|l|l|}
\hline Date & $\begin{array}{l}\text { Size of Story (in } \\
\mathrm{cm}^{2}\end{array}$ & $\begin{array}{l}\text { Placement \& } \\
\text { Treatment }\end{array}$ & Environmental Issue & $\begin{array}{l}\text { Total Area (in } \\
\mathrm{cm}^{2}\end{array}$ \\
\hline $20-02-2016$ & No space & -------- & ------- & $00 / 51408$ \\
\hline $21-02-2016$ & No space & ------- & ------ & $00 / 47736$ \\
\hline $22-02-2016$ & 120 & P-2 & Water conservation & $120 / 47736$ \\
\hline $23-02-2016$ & 180 & P-4 & Pollution & $180 / 47736$ \\
\hline $24-02-2016$ & No space & --------- & ------- & $00 / 47736$ \\
\hline $25-02-2016$ & No space & ------- & ------- & $00 / 47736$ \\
\hline $26-02-2016$ & No space & ------- & -------- & $00 / 47736$ \\
\hline
\end{tabular}

On the basis of table no.2 we can say that most of environmental stories are based on pollution and climate change. During above mentioned time period, only few articles have been published in this paper.

C. Hindi Daily Hindustan- Hindustan is one of leading news paper of India. It is also popular among youth. It has created a good place among its reader.

Table No. 3

\begin{tabular}{|c|c|c|c|c|}
\hline Date & $\begin{array}{l}\text { Size } \\
\left(\mathrm{cm}^{2}\right)\end{array}$ of $\quad$ Story & $\begin{array}{l}\text { Placement } \quad \& \\
\text { Treatment }\end{array}$ & Environmental Issue & Total Area $\left(\mathrm{cm}^{2}\right)$ \\
\hline $20-02-2016$ & $\begin{array}{l}160 \\
40\end{array}$ & $\begin{array}{l}\mathrm{P}-10 \\
\mathrm{P}-16\end{array}$ & $\begin{array}{l}\text { CIM } \\
\text { Cyclone }\end{array}$ & $200 / 33048$ \\
\hline $21-02-2016$ & 96 & $\mathrm{P}-5$ & Climate Change & $96 / 33048$ \\
\hline $22-02-2016$ & $\begin{array}{l}30 \\
21\end{array}$ & $\begin{array}{l}\text { P-3 } \\
\text { P-5 }\end{array}$ & $\begin{array}{l}\text { Climate Change } \\
\text { Weather }\end{array}$ & $111 / 33048$ \\
\hline
\end{tabular}




\begin{tabular}{|l|l|l|l|l|}
\hline & 60 & P-9 & Clean Ganga & \\
\hline $23-02-2016$ & 160 & P-10 & Pollution & $160 / 29376$ \\
\hline $24-02-2016$ & 164 & P-6 & Climate Change & $164 / 33048$ \\
& & & $\begin{array}{l}\text { NGT } \\
\text { Pollution }\end{array}$ & $292 / 33048$ \\
\hline $25-02-2016$ & 128 & P-3 & Water Preservation, & $384 / 29376$ \\
& 164 & P-5 & $\begin{array}{l}\text { Pollution, } \\
\text { Pollution }\end{array}$ & \\
\hline $26-02-2016$ & 136 & P-3 & P-7 \\
& 88, & P-14 & ver & \\
& 160 & thatf & & \\
\hline
\end{tabular}

On the basis of table no. 3 we can say that this paper has given very some effective stories. Few articles of environmental activist have been published on editorial page. Main issues raised by this paper are pollution, climate change and associated problem. Only few stories have been found supported by photographs.

D. Hindi daily 'Navbharat Times'- Navbharat Times is a leading news paper of Delhi- NCR. It is at top position on the basis of circulation.

Table No-4

\begin{tabular}{|c|c|c|c|c|}
\hline Date & Size of Story & $\begin{array}{l}\text { Placement \& } \\
\text { Treatment }\end{array}$ & Environmental Issue & $\begin{array}{l}\text { Total } \\
\text { Area }(54 * 34 * n)\end{array}$ \\
\hline $20-02-2016$ & $\begin{array}{l}120, \\
98\end{array}$ & $\begin{array}{l}\text { P-4, } \\
\text { P-7 }\end{array}$ & $\begin{array}{l}\text { Pollution, } \\
\text { Water crisis }\end{array}$ & $218 / 29376$ \\
\hline 21-02-2016 & $\begin{array}{l}160 \\
84\end{array}$ & $\begin{array}{l}\text { P-3 } \\
\text { P-7 }\end{array}$ & $\begin{array}{l}\text { Water crisis } \\
\text { Pollution }\end{array}$ & $244 / 29376$ \\
\hline $22-02-2016$ & $\begin{array}{l}120 \\
84\end{array}$ & $\begin{array}{l}\text { P-2 } \\
\text { P-3 }\end{array}$ & $\begin{array}{l}\text { Pollution } \\
\text { Pollution }\end{array}$ & $204 / 29376$ \\
\hline $23-02-2016$ & $\begin{array}{l}98 \\
120\end{array}$ & $\begin{array}{l}\mathrm{P}-3 \\
\mathrm{P}-4\end{array}$ & $\begin{array}{l}\text { NGT } \\
\text { Pollution }\end{array}$ & 29376 \\
\hline $24-02-2016$ & No space & $\begin{array}{ll}---- \\
\end{array}$ & -------- & $00 / 29376$ \\
\hline $25-02-2016$ & $\begin{array}{l}120, \\
216, \\
200, \\
160 \\
144\end{array}$ & $\begin{array}{l}\text { P-1 } \\
\text { P-5 } \\
\text { P-7 } \\
\text { P-11 } \\
\text { P-13 }\end{array}$ & $\begin{array}{l}\text { Water crisis } \\
\text { CIM } \\
\text { Water crisis } \\
\text { Weather } \\
\text { Drought }\end{array}$ & $840 / 36720$ \\
\hline $26-02-2016$ & 360 & P-4 & Water conservation & $360 / 40392$ \\
\hline
\end{tabular}

On the basis of table no.4 we can say that most of stories published in 'Navbharat Times' are based on clean pollution. It also covered the issue of pollution in Yamuna and its impact on health. It has also analyzed the increasing pollution level in city and pointed out its cause. However little space has been given for environmental issues but issues raised by the paper are strong.

Conclusion- Environment is the most important part of our life. Nature, mother of human being, has blessed us with a beautiful environment. Environment is a sum total of precious things like water, air, land and all living and non-living things. As per environmental determinism, environment decides human lifestyle, culture their social behavior and hence, it directs growth and development of humankind. Our religious books advocate environmental protection. We can find thousands rhymes and shlokas on various 
environmental issues where the importance of environmental components are described and worshiped as devta. Our Vedas describes the importance of everything present in environment and concept of sustainable development. It teaches us, if we want to save ourselves, we need to save our environment. Print media, has raised environmental issues time to time and sensitize people towards environment. It also helps government to communicate environmental policy and helps people to understand it. This study shows environmental issues like pollution, climate change, calamity due to climate change, and impact of industrialization and technology on species have been raised by national dailies. However the space given to environmental issues is not sufficient in any newspaper and hardly $5 \%$ space has been given by any paper.

\section{References-}

1. Yajurveda 36:17

2. Jaiswal P.S \& Nishtha (2011), Environmental Law, Allahabad law Agency, P-6

3. Bavadam, Lyla (2010), Environment Stories, among the Most Challenging, in The Green Pen, Acharya, Keya \& N. Frederick (ed.), Sage, New Delhi, Page-123.

4. Sharma P.D. (2012), Ecology and Environment, Rastogi Pub., Meerut, page-374.

5. Saxena H. M. (2003), Environmental Geography, Rawat Pub., Jaipur, Page-57.

6. Jaiswal P.S \& Nishtha (2011), Environmental Law, Allahabad law Agency, P-6

7. Kale S.L.\& Vipin Choudhary, Environmental Crisis : Solution Lies in Religious Teachings in Environment Management Practices: An Indian Outlook (ed.), Himanshu Pub, Udaipur,2007, p40

8. Kaushik Anubha \& Kaushik C.P. (2009), Perspectives in Environmental Studies, New Age International Pub., New Delhi, Page-193.

9. Rajagopalan R. (2011), Environmental Studies from Crisis to Cure, Oxford Pub., New Delhi, Page-13 